\title{
Chinese traditional national concept analysis
}

\author{
Jianping LIU \\ Sichuan Agricultural University \\ Sichuan, China
}

\begin{abstract}
Chinese traditional culture suffered serious tests. In the face of the inflow of western modern political and culture, "a home under the sun", this concept of the traditional national status is changing in the structure of China's national identity consciousness, and the new national identity consciousness is reshaping. But "a home under the sun" traditional state concept still plays a role all the time in today's Chinese society. Therefore, in this paper, through the analysis of the traditional national concept of home and state isomorphic, and the profound comparison between western traditional national concept and Chinese traditional national, I finally give a brief comment on the influence of traditional Chinese national idea on modern society.
\end{abstract}

Keywords- political culture; National idea; Economy; Democracy

\section{INTRODUCTION}

"Lecture room", a column that CCTV launched, has attracted a lot of people who are interested in Chinese literature. Since founded, it set off a wave of retro trend in the field of Chinese culture. And the stage teaching scholars also began to become the new stars, like Yi Zhongtian who lecture "the romance of three kingdoms", "the Analects of Confucius" from Yu Dan, and Zhou Ruchang who study redology, etc. When we carefully taste the column's name, it is not hard to find that it contains the national concept of Chinese traditional culture --"a home under the sun". Hundreds can be understood as the content of the teaching covers all aspects, and it can also be a synonym for hundred schools of thought and agree that family is the home, country is everybody. This is one contains the Chinese traditional national idea of "a home under the sun.

One, connotation of national idea "a home under the sun" in Chinese traditional political culture

So-called national concept, its essence is about the country's power source, which is the "Legitimacy" of state power. In order to explain the tradition national idea of "a home under the sun", we first have to clarify the connotation of the two words "kingdom" and "home" in the traditional culture.

Xia and Shang period, national idea of "a home under the sun" hasn't formed. Xia and shang dynasties are in the central with peripheral "party state" everywhere. They accept the conferring of the kingdom from the central and establish a "total master" subordinate relationship. People's identification of the concept of "nation" includes two aspects: one is for their own nation identity and the other is for the identity of "the world of the status" of "central country".

Until the Western Zhou dynasty, the Zhou dynasty adopt the system of enfeoffment. At that time, "state" refers to the charming manor that the Western Zhou dynasty seal the vassal states and "state" also called "country"; home refers to the doctor's office, called "home" or "family". The relationship between the western Zhou dynasty and the vassal is no longer a "total master" subordinate relationship, but the branch of this political pattern that the western Zhou dynasty monarch claimed themselves the son of heaven and believe "the world" is given by god. Therefore, son of heaven is representing the country, and national relationship is marked by political rights. At this time the traditional unified national situation is forming, the concentrated reflection of Chinese traditional concept has been established on the concept of sovereignty of countries.

Qin Shihuang unified the six countries, marking the unified national situation has formed. The Qin dynasty implement the system of prefectures and countries, indicating each governors and the Qin dynasty would be no longer alliance relationship, but by the Qin dynasty unified the jurisdiction of the administrative units. In the sovereign state, the monarch is not only the parents of the royal palace but also the common people's parents. This is the home countries isomorphic, jun the integrated concept of "a home under the sun" countries.

In traditional Chinese culture, therefore, "home" have both political power and consanguinity moral restraint the double function of patriarchal clan system, and it is the basic unit of a series of social activities. It not only has the meaning of "home", but also refers to QingDaFu blocked the political field. With the human society development to a certain stage, "Country" is formed. With the view of Marxism, it is the tool of class rule, standing above social force. In modern legal society, individuals with its own independent personality became the nation's minimum units, but in China ancient society, the family is the smallest unit of the country, and the country is constructed on the basis of the family. No matter in small family or country, father is the parent of small family while the king is the parent of all. "three cardinal guides", ruler guides subject, father guides son, husband guides wife, as the ethics will intertwined everyone in this society in a tight network, constitute the China unique "home" and "country" fusion as the integration of traditional national concept, i.e., the home country isomorphic, jun the integrated concept of "a home under the sun" countries. 
Visibly, the national idea of "a home under the sun" is based on the ethics of home countries isomorphic national outlook, such as the rites, LiYun, said: "so the sage in the world for a resistance, in China, for one, the meaning of, also will know the feeling, the monarch in his righteousness, Ming in its reach on its developing, and then we can." Saint compare countries to home, regard the world as a home, know the stakes, good at dealing with all kinds of advantages and disadvantages, and truly make a difference.

\section{COMPARISON OF THE CHINESE TRADITIONAL CONCEPT OF NATION AND WESTERN COUNTRIES TRADITIONAL NATIONAL CONCEPT}

Chinese traditional national concept is the ethical country isomorphic, while western traditional national concept is based on contract theory that based on the citizen's "public will" and ceding some or all rights, country is established on the theory of natural law. Between Chinese traditional national idea based on the ethics and western traditional national concept on the contract theory, there is a big difference in the countries produce way, material foundation, cultural soil and so on.

\section{A. Different explanation of the concept of country}

In ancient China, "China" and "home" are two separate concepts. The western Zhou dynasty, the "country" refers to the vassal states sealed by the western Zhou dynasty emperor and "home" refers to the doctor's office. So state concept of "a home under the sun" is formed by consanguinity link and home and country isomorphic. In the west, there is the ancient Greek polis and the Roman republic, but "home" and "country" are regarded as two unrelated things for state refers to a political community while the family refers to the blood group of society, so they have different authority property and status. In the country, people should be primary, and secondly politicians; In the family, parents should be head of the family, and families is complementary. Parent-child relationships unlike China with a strict hierarchy of paternalism, it has a certain ethical limits.

\section{B. The different origins of the nation}

Countries in ancient China is on the basis of the clan organization, set up by war between the tribes. In ancient times, there are two larger tribe on the Central Plains: one is the Yan emperor tribe, the other is the Huang emperor tribe. Later, for the benefit of the tribal the two sides align, that's why we call ourselves descendants of the Yan and Huang Emperors, which was permeated with blood relationship. Therefore, in Chinese culture, national produced directly from families, and into the family.

In the west, contract founding idea occupies an important position. In the 17th century and 18th century, the social contract theory was in a dominant position in the western political culture, although many scholars have a different interpretation to the specific conditions of a social contract as well as the state of nature, but they are all on the one problem: the contract is that the consent of people of the theory form that logically obtains the essence or nature of state or government, or standards of government's good and evil. However, the moral standards, the vast majority of cases, is based on the sanctity of private property rights, to life, liberty and security of the content of human rights.

\section{The different economic foundation that national idea based on}

Since ancient times China has formed the small-scale peasant economy that follows the nature law with household unit, and become basic economic form and mode of production in China several thousand years of feudal society. Small-scale peasant economy, larger dispersion mode of production is beneficial for the feudal rulers. Since the Qin and Han dynasties, the state advocates physiocracy policy. Han dynasty even adopts a registration system that see a household as a unit for residents, combining the number of population with land, accordingly to which to levy taxes, making the farmers tie firmly to the land. Under such economic foundation, on the one hand, it depends on nature greatly and makes the ancients often put their hopes on the day, and the king claimed to be son of the heaven, whose right is arranged by god. Therefore, it easily leads to absolute obedience consciousness of Kings. On the other hand, the effective utilization of land cannot leave the farmers in the land, so the subjectivity of people is more concerned about. The content of the two aspects of heaven and man in the field of culture contributed to the formation of the concept of "the unity of nature and humanity", laid a solid foundation for the formation of the concept of a home under the sun.

\section{D. the different soil national culture based}

Chinese traditional culture has a very important influence on Chinese traditional political system. Firstly, the idea of "the unity of nature and humanity" pave the way for the ruling class with a layer of mysterious color. The king is the son of heaven, but not ordinary people. It's orders is god's will, so the people must obey. Jun is the world. Secondly, the traditional concept of patriarchal clan, parents is the head of the house, the patriarch is host of the race, the king is a master of the country, the father is the head of the family, and the king is the Lord of all, so the son to father's filial piety and minister of monarch loyalty is consistent, provides the legal basis for the idea isomorphic regime. Thirdly, the traditional hierarchy, starting from the Zhou dynasty in the ritual culture, later further improved by Confucianism that relation between emperor and minister, father and son, everyone has their own duty from small home to comply extended to the whole society, laid the ideological basis for the idea of "a home under the sun".

The cultural background of the western contract is considerably different from China. After the medieval, Renaissance and religious reform movement began to undergo in the West Europe, and the bourgeois liberal thought began to sprout. In the Renaissance, the bourgeoisie against the feudal theology with humanism thoughts. They advocate rational, against the divine; Advocate individual character freedom, against the feudal shackles; Advocate individual earthly happiness, against the church's asceticism. In the reformation, the bourgeoisie penetrate freedom, equality, democracy into their thought. These movements 
secularize the western political thought, and contract theory is the performance of this change.

\section{THE INFLUENCE OF THE TRADITIONAL CHINESE NATIONAL IDEA ON MODERN SOCIETY}

In western culture, the country is to the form of substitution for family while in the Chinese culture, the country is to dissolve into the family and the traditional national concept of home country isomorphic still has a great influence on modern society.

First, the national idea of "a home under the sun" make Chinese people put national interests above personal interests. The national honor is supreme, resulting in intense patriotism. The Wenchuan earthquake take Chinese people great material loss as well as tremendous mental trauma, but the unity of the Chinese people left a deep impression to the world. People throughout the country and even the Chinese, overseas Chinese, everybody became like a family, dedicating strength and hope Sichuan, more hope China to cheer up. We are descendants of the dragon, our blood is thicker than water, we are one family to be deeply attached to each other, and regard China as a billion or more members of the family.

Then, based on the ethics of traditional national concept associated with the rule of law construction. On the one hand, traditional ethical state concept enriches the modern political principles, forming the road of rule by law with Chinese characteristics. Political morality is very dangerous, but political moral requirement is necessary, and moral requirements for legislation and law enforcement must be adhered to. Lost the political law system of justice and of value judgment, the political legitimacy foundation will be lost. On the other hand, adhering to the rule of law needs to wary of the proliferation of the rule by man. Under the traditional national concept of isomorphic home countries, subject type political culture contains the political rule lacking of legal basis, and the rule of traditional norms and the will of the monarch is the main ruling foundation. Object who is subjected to is not formulated that is worked out or recognized by people, but individual rulers who occupy a dominant position should subject to or obey the traditional. But this rule by man in accordance with the specification and individual is to avoid and solve in the country under the rule of law. Therefore, traditional national concept based on the ethics and the rule of law is a inseparable connection, which can promote the smooth progress of the construction of the rule of law, and can also become the obstacles. Only the right attitude towards relationship between political moralization and moral requirements, the strategy of combining rule by law and rule by virtue can be promoted.

Second, the subject type political culture ease the contradiction in the process of political modernization in China, but also hindered the process of political modernization. Almon said: "the political culture is a nation in a particular period of popular a political attitudes, beliefs and emotions." Subjects political culture, a corresponding political culture to the home country isomorphic traditional national concept, endogenous political culture cultivate people the characteristics of "endure", providing a stable guarantee for the political system changes. But at the same time, the long cultivated in the concept of people has a very deep servility, to nurture their civic consciousness is not achieved overnight. Party congress report pointed out that the rule of law constitutes the essential requirement of socialist democracy. Adhere to the citizens are equal before the law and safeguard social fairness and justice. In traditional national concept of "a home under the sun", the king is the national symbol of the highest position and king's will is law. Culture soil of the democratic politics development is the participated (citizen) political culture that requires more people to involved in the political process, influencing the political decisions. Therefore, to promote the process of China's political modernization, needs to nurture citizens' political culture..

\section{CONCLUSIONS}

Under the background of globalization, Chinese traditional culture and western culture had the intense collision. Under the influence of the western democratic politics, the traditional Chinese national idea is gradually losing its luster, but in the process of forming a new national concept, we should inherit the positive aspects that can promote political modernization process and overcome the other side that does not adapt to the development of the political system.

\section{References}

[1] Lei Yi. Modern Chinese national idea change with the traditional thought origin [J]. Journal of leader, 2013 (55).

[2] Liu Yong. Based on the experience of the Oriental nation, national idea [J]. Journal of yancheng institute of technology, 2009 (9).

[3] Bai Weichun. Political culture, traditional Chinese and western comparative analysis [J]. Journal of northeast normal university press, 2001:131.

[4] Wang Shiying. The connotation of the word "family" of traditional China [J]. Journal of old building, 2009 (24).

[5] Bai WeiChun. Political culture, traditional Chinese and western comparative analysis $[\mathrm{J}]$. Journal of northeast normal university press, 2001:220.

[6] Xu Datong. Western political thought [J]. Journal of Tianjin education press, 2002:123.

[7] Xu Datong. Western political thought [J]. Journal of Tianjin education press, 2002; 92.

[8] The Gabrielle a. Almon, Cassini Eph. Civic culture [M]. New Jersey: Princeton university press, 1963:17-18. 